\title{
The Toll-like receptor ligand, CpG oligodeoxynucleotides, regulate proliferation and osteogenic differentiation of osteoblast
}

Wenwen Yu ${ }^{1,2}$, Yi Zheng ${ }^{1}$, Hongyan Li ${ }^{1}$, Hongbing Lin' ${ }^{1}$ Zhen Chen ${ }^{1}$, Yue Tian ${ }^{1}$, Huishan Chen ${ }^{1}$, Peipei Zhang ${ }^{1}$, Xiaowei $\mathrm{Xu}^{1}$ and Yuqin Shen ${ }^{1 *}$

\begin{abstract}
Background: This study aimed to investigate the regulation of $\mathrm{CpG}$ oligodeoxynucleotides (ODNs) on proliferation and osteogenic differentiation of MC3T3 cells.

Methods: The laser co-focusing and flow cytometry assay were employed to detect cell uptake of CpG ODN 2006. Twelve ODNs were sythesized, and their effects on proliferation and differentiation were detected by MTT and alkaline phosphatase (ALP) activity assay. Flow cytometry assay was used to examine the regulation of CpG ODN on cell cycle. Quantitative real-time PCR (qRT-PCR) and western blot were used to evaluate the regulation of CpG ODN on mRNA and protein expression of osteogenic differentiation genes.

Results: The phosphorothioate CpG ODN 2006 could efficiently enter the MC3T3 cells in $1 \mathrm{~h}$ and locate in the cytoplasm. The MTT assay demonstrated CPG ODNs could promote MC3T3 cell proliferation and differentiation in the early stage, and gradually attenuated along with the increase of treating time, except for BW001 and FC001. qRT-PCR assay demonstrated that all the $12 \mathrm{CpG}$ ODNs could promote the relative expression level of osteogenic differentiated genes, SP7 and OCN. In addition, western blot analysis suggested the CpG ODNs of BW001 and FC001 could increase the protein expression of P2 $7^{\mathrm{Kip} 1}$ and Runx2 and decrease the protein expression of cyclin D1.

Conclusion: The selected CpGODNs may be a potential gene therapy for bone regeneration of periodontitis.

Keywords: Periodontitis, CpG ODN, Osteoblast, Proliferation, Differentiation
\end{abstract}

\footnotetext{
* Correspondence: shenyqjulu@126.com

${ }^{1}$ Department of Periodontics, School and hospital of Stomatology, Jilin

University, 1500 Qinghua Road, Changchun, Jilin 130021, China

Full list of author information is available at the end of the article
}

(c) The Author(s). 2020 Open Access This article is licensed under a Creative Commons Attribution 4.0 International License, which permits use, sharing, adaptation, distribution and reproduction in any medium or format, as long as you give appropriate credit to the original author(s) and the source, provide a link to the Creative Commons licence, and indicate if changes were made. The images or other third party material in this article are included in the article's Creative Commons licence, unless indicated otherwise in a credit line to the material. If material is not included in the article's Creative Commons licence and your intended use is not permitted by statutory regulation or exceeds the permitted use, you will need to obtain permission directly from the copyright holder. To view a copy of this licence, visit http://creativecommons.org/licenses/by/4.0/. The Creative Commons Public Domain Dedication waiver (http://creativecommons.org/publicdomain/zero/1.0/) applies to the data made available in this article, unless otherwise stated in a credit line to the data. 


\section{Background}

Periodontitis is caused by bacterial infection and natural immune response, and the cardinal symptoms are inflammation and bone absorption. Toll-like receptors (TLRs) are pathogen pattern recognition receptors, which play important roles in immunity response [1]. TLR9 could activate nuclear factor (NF)-kappa B and mitogen-activated protein kinase (MAPK) by canonical MyD88-interleukin 1 receptor-associated protein kinase (IRAK)-tumor necrosis factor receptor-associated factor 6 (TRAF6) pathway to initiate anti-infection immune response [2]. Furthmore, the TLR9 also expresses on the suface of osteocytes to regulate bone metabolism [3]. Agents involved in lipopolysaccharide signal transduction pathways induced by TLR has been proposed to be potential strategy for treating inflammation disease, such as allergic diseases [4]. Due to the significance of TLR on inflammatory and bone formation, we hyperthesized that agents that could target TLR might also have potential for treating periodontitis.

Bacterial DNA is a kind of pathogen-associated molecular pattern that specially recognizes TLR, and its immunological basis is the unmethylated CpG motif [5]. Studies have shown that either CpG-based sequences of bacterial or synthetic $\mathrm{CpG}$ oligodeoxynucleotides (ODNs) could strongly regulate immune function, which can quickly trigger the body to resist infection [6]. CpG ODN is widely used in the research and treatment of immunology. The mouse model and clinical trials have confirmed the immuno-stimulating effects of synthetic CpG ODN [7] on various diseases, including cancer, allergic diseases, asthma and infectious diseases $[8,9]$. However, the role of CpG ODN on bone metabolism is far from understanded.

The previous researches have reported the tight association between CpG ODN and osteocytes. CpG ODN can regulate the differentiation of osteoclasts by binding to TLR9 $[3,10]$, and this regulation could also be indirectly achieved by targeting TLR9 of osteoblasts' surface [10]. Actived TLR9 on osteoblast's surface initiates extracellular signal-regulated protein kinase and P38 to release tumor necrosis factor $\alpha$, then enhancing the expression of macrophage colony-stimulating factor to regulate osteoclasts [11]. The CpG ODN yet plays a positive role in osteogenic differentiaion of bone mesenchymal stem cells [12] and pre-osteoblasts [13].

In the past dacades, serveral CpG ODNs have been designed and their roles have been investigated widely [14, 15]. However, there were few studies about the relation of $\mathrm{CpG}$ ODN on osteogenic differentiation in previous researches. Shen et al. and Feng et al. have reported the effects of multiple CpG ODNs on bone marrow mesenchymal stem cells and MG63 cells $[12,13]$. Nevertheless, the molecular mechanism of these CpG ODNs are largely unknown. In this study, we prepared 12 ODNs and investigated their roles on proliferation and differentiation of osteoclasts. We aimed to provide some CpG ODNs that have potential to be applied for bone regeneration on the basis of their anti-inflammation ability in treating periodontitis.

\section{Materials and methods \\ Cell culture}

The MC3T3 cells (GNM15) were purchased from Cell bank of Chinese Academy of Sciences (Shanghai, China) and were cultured in high glucose-Dulbecco's modified Eagle's medium (DMEM) supplemented with 10\% fetal bovine serum (FBS) and $100 \mathrm{U} / \mathrm{mL}$ penicillin and $100 \mathrm{mg} / \mathrm{mL}$ streptomycin (ThermoFisher, Carlsbad, CA, USA). Cells were cultured in humidified atmosphere at $37{ }^{\circ} \mathrm{C}$ and $5 \% \mathrm{CO}_{2}$.

Thirteen ODNs, including 2006, FC003, SAT05f, SAT05d, MS19, BW001, FC001, FC002, BW006, YW002, YW001, FC004, and MT01 were sythesized in Takara (Dalian, China), and the sequence was listed in Table 1.

The MC3T3 cells were divided into 14 groups, including cells treated with phosphate buffer saline (PBS, control group), cells treated with ODN 2006 (positive control), and cells treated with the 12 kinds of ODNs.

\section{Laser co-focusing detection}

MC3T3 cells were seeded on the glass slides in a 6-well plate at a density of $2 \times 10^{4}$ cells/well and incubated for $24 \mathrm{~h}$. Then, the cells were treated with $2 \mu \mathrm{g} / \mathrm{mL}$ Cy5ODN 2006 for $1 \mathrm{~h}$, washed with PBS for three times and fixed by $4 \%$ paraformaldehyde for $10 \mathrm{~min}$. After being washed with $0.1 \%$ Triton X-100, the actin-tracker green

Table 1 Gene sequence of the 13 ODNs and the primer sequence for quantitative real-time PCR

\begin{tabular}{|c|c|c|}
\hline Number & Name & Sequence \\
\hline & 2006 & 5'-TCGTCGTITTGTCGTITGTCGTT-3' \\
\hline 1 & FC003 & 5'-ТСТСТСТСТСТСТСТСТСТСТСТС-3' \\
\hline 2 & SAT05f & 5'-ССТССТССТССТССТССТССТССТ-3' \\
\hline 3 & SAT05d & 5'-СТСТСТСТСТСТСТСТСТСТСТСТ-3' \\
\hline 4 & MS19 & 5'-AAAGAAAGAAAGAAAGAAAGAAAG-3' \\
\hline 5 & BW001 & 5'-TCGTCGGGTGCGACGTCGCAGGGGGG-3' \\
\hline 6 & FC001 & 5'-TCGGGGACGATCGTCGGGGGG-3' \\
\hline 7 & FC002 & 5'-TCGTCGACGTCGTTCGTTCTC-3' \\
\hline 8 & BW006 & 5'-TCGACGTTCGTCGTTCGTCGTTC-3' \\
\hline 9 & YW002 & 5'-TCGCGAACGTTCGCCGCGTTCGAACGCGG-3' \\
\hline 10 & YW001 & 5'-TCGCGACGTTCGCCCGACGTTCGGTA-3' \\
\hline 11 & FC004 & 5'-TCGCGAACGTTCGCCCGATCGTCGGTA-3' \\
\hline \multirow[t]{4}{*}{12} & MT01 & 5'-АСССССТСТАСССССТСТАСССССТСТ-3' \\
\hline & $\beta$-actin & $\begin{array}{l}\text { 5'-CATCCGTAAAGACCTCTATGCCAAC-3' } \\
\text { 5'-ATGGAGCCACCGATCCACA-3' }\end{array}$ \\
\hline & SP7 & $\begin{array}{l}\text { 5'-AAGTTATGATGACGGGTCAGGTACA-3' } \\
\text { 5'-AGAAATCTACGAGCAAGGTCTCCAC-3' }\end{array}$ \\
\hline & OCN & $\begin{array}{l}\text { 5'-ACCATCTITCTGCTCACTCTGCT-3' } \\
\text { 5'-CCTTATTGCCCTCCTGCTTG-3' }\end{array}$ \\
\hline
\end{tabular}


work fluid (Beyotime Biotech Inc., Jiangsu, China) was added to cover the cells for $30 \mathrm{~min}$ in dark. The nucleus were stained by DAPI (Beyotime Biotech Inc., Jiangsu, China) for additional $5 \mathrm{~min}$. After washing by PBS, the glass slides were fixed by $50 \%$ glycerol and detected by laser cofocusing apparatus (FV1000, Olympus, Osaka, Japan).

\section{Flow cytometry (FCM) assay}

After transfected with Cy5-ODN for $1 \mathrm{~h}$, cells were collected in the dark, then washed and centrifuged for three times before being transferred into transparent glass tubes. The indices of flow cytometry under green light were set at $540 \mathrm{~nm}$ wavelengths. The ratio of the Cy5positive cells/total cells was determined quantitatively.

MC3T3 cells after co-culturing with the 12 kinds of ODNs and ODN 2006 for $72 \mathrm{~h}$ were trypsinized, collected, centrifuged and washed by cold PBS, then fixed by cold $70 \%$ ethyl alcohol for $24 \mathrm{~h}$ under $4{ }^{\circ} \mathrm{C}$. After that, the cells were centrifuged and washed again to discard $70 \%$ ethyl alcohol. Then, the cells were stained with 1 $\mathrm{mL}$ propidium iodide (PI)/TritonX-100 staining solution (7sea biotech, Shanghai, China) at $37{ }^{\circ} \mathrm{C}$ for $30 \mathrm{~min}$. Finally, the samples were tested by FACS caliber (BD Biosciences, San Jose, CA USA) and the cell ratio of G1, S and G2 phase was examined by using FlowJo software (BD Biosciences).

\section{4,5-Dimethylthiazol-2-yl)-2,5-diphenyltetrazolium (MTT) assay}

The MC3T3 cells were seeded into a 96-well plate with $3 \times 10^{3}$ per well. After $24 \mathrm{~h}, \mathrm{PBS}$, ODN 2006 and the 12 kinds of ODNs were respectively added at a concentration of $2 \mu \mathrm{g} / \mathrm{mL}$. After co-culturing for 24, 48and $72 \mathrm{~h}, 5$ $\mathrm{mg} / \mathrm{mL}$ MTT (Sigma-Aldrich, St Louis, MO, USA) was added to each well and incubated for another $4 \mathrm{~h}$. Then, the MTT solution was removed and $150 \mu \mathrm{L}$ DMSO (Sigma-Aldrich, St Louis, MO, USA) was added to dissolve the formazan crystals for $10 \mathrm{~min}$. Absorbance was examined at $492 \mathrm{~nm}$ by a GF-M3000 microplate reader (Shandong, China).

\section{Alkaline phosphatase (ALP) activity assay and staining}

The MC3T3 cells in the 96-well plate were cultured in osteogenic differentiation medium $\left(1 \times 10^{-8} \mathrm{M}\right.$ dexamethasone, $10 \mathrm{mM} \beta$-glycerophosphate, and $50 \mu \mathrm{g} / \mathrm{mL}$ L-ascorbic acid) (Sigma-Aldrich, St Louis, MO, USA), then lysed using $1 \%$ Triton X-100 after treating with ODNs and 2006 for 24, 48 and $72 \mathrm{~h}$. The total ALP activity and protein concentration were evaluated by using an ALP assay kit (Jiancheng Bioengineering institute, Nanjing, Jiangsu, China) and a bicinchoninic acid (BCA) protein assay kit (Beyotime Biotech Inc., Jiangsu, China). The ALP levels were normalized to the total protein content.
MC3T3 cells were seeded in a 24-well plate and were cultured in a conditioned medium with ODNs and ODN 2006 for 7 days. Then, ALP staining was performed using BCIP/NBT ALP color development kit (Beyotime Biotech Inc., Jiangsu, China). The stained cells in each group were photographed, and cell staining was independently repeated at least three times.

\section{Quantitative real-time reverse transcription polymerase chain reaction (qRT-PCR)}

Total RNA of MC3T3 cells were extracted by Trizol reagent (ThermoFisher), and reverse-transcribed in cDNA using PrimerScript ${ }^{\circledR}$ RT reagent kit (Takara). After that, qRT-PCR was performed on MxPro Mx3005P system (Agilent Technologies, Santa Clara, CA, USA) using SYBR Green Premix Ex Taq kit (Takara). The cycling conditions of mRNAs were as follows: $95{ }^{\circ} \mathrm{C}$ for $30 \mathrm{~s}$, followed by 40 cycles of $95^{\circ} \mathrm{C}$ for $5 \mathrm{~s}, 55^{\circ} \mathrm{C}$ for $30 \mathrm{~s}$, and $72{ }^{\circ} \mathrm{C}$ for $1 \mathrm{~min}$. The primer sequence was listed in Table 1 . The relative expression levels were calculated by $2^{-\Delta \Delta C t}$ method with $\beta$-actin as internal control. The obtained values were averaged from triplicate measurements.

\section{Western blot analysis}

Total protein of MC3T3 cells were harvested with RIPA lysis buffer and quantified with a BCA assay kit (Beyotime). Proteins were separated on $12 \%$ SDS-polyacrylamide gels and transferred to polyvinylidene fluoride membranes (Millipore, Billerica, MA, USA). These membranes were blocked with $5 \%$ bull serum albumin in Tris buffered saline with Tween 20 and incubated with the following primary antibodies at $4{ }^{\circ} \mathrm{C}$ overnight: cyclin D1 (1:500, A2708, ABclonal, Wuhan, China), SP7 (1:1000, ab94744, Abcam, Shanghai, China), OCN (1:650, A5786, ABclonal), Runx2 (1:500, A2851, ABclonal), P27 ${ }^{\text {Kip1 }}$ (1:500, A2692, ABclonal), and $\beta$-actin (1:100000, AC026, ABclonal). Horseradish peroxidase-conjugated anti-rabbit IgG $(\mathrm{H}+\mathrm{L})$ secondary antibodies were added (1:3000, AS014, ABclonal) and incubated at $25{ }^{\circ} \mathrm{C}$ for $1 \mathrm{~h}$. The signals were detected using an ECL chemiluminescence kit (7Sea biotech, Shanghai, China) by Tanon 5200 (Tanon, Shanghai, China).

\section{Statistical analysis}

Statistical analysis was conducted by SPSS version 20.0 (IBM). All experiments were performed at least three times. Results were presented as the mean \pm standard deviation (SD). Differences among groups were compared by one-way analysis of variance with Bonferroni post hoc test. A two-tailed $P$ value $<0.05$ was considered statistically significant.

\section{Results}

\section{CpG ODN could be internalized by MC3T3 cells}

In order to investigate whether ODNs could be uptaken by MC3T3 cells and to check its distribution in cells, we 
performed a laser confocal detection using ODN 2006. The results showed that the Cy5-labeled ODN 2006 could quickly penetrate into MC3T3 cells within $1 \mathrm{~h}$, and the Cy5-ODN 2006 positive cells were estimated to be more than $90 \%$ according to fluorescence microscopy (Fig. 1a) and flow cytometry assay (Fig. 1b). The high magnification images displayed that ODN 2006 was mainly distributed in the cytoplasm and barely enter the nucleus (Fig. 1c). These results indicated that phosphorothioate ODN could enter cells quickly and efficiently and is mainly distributed in the cytoplasm.

\section{CpG ODNs influenced cell proliferation and cell cycle of MC3T3 cells}

Bone regeneration mainly included proliferation and differentiation of osteoblasts. Therefore, we further investigated the effect of ODNs on MC3T3 cell proliferation. The MTT assay revealed that most ODNs could significantly increase cell proliferation compared with control group except for BW001 and FC001 (number 5 and 6, $P<$ $0.05)$ at $24 \mathrm{~h}$. However, these effects of ODNs on cell proliferation gradually tended to be reduced along with the treating time. At $72 \mathrm{~h}$, only BW001 and FC001 showed significant declining cell viability compared with control group and positive control group $(P<0.05$, Fig. 2a). As a result, we presented that the effect of $\mathrm{CpG}$ ODN on proliferation of MC3T3 cells occurred in the early stage, and gradually weakened to normal. However, it is interestingly that the inhibition effect of BW001 and FC001 on proliferation retained with extended time.
In order to investigate the underlying mechanism of inhibition of cell proliferation of BW001 and FC001, we further conducted cell cycle assay. The flow cytometry results revealed that BW001 and FC001 could decrease the cell percentage of G1 and S phase, but greatly increase the cell percentage of G2 phase, compared with both PBS and ODN 2006 groups (Fig. 2b, c). These results suggested that BW001 and FC001 might inhibit cell proliferation by decreasing cells in G1 and S phase and blocking cells in G2 phase.

\section{CpG ODN regulated osteogenic differentiation of МС3Т3 cells}

Subsequently, we detected the effect of ODN on MC3T3 cell differentiation. To select the effective ODNs on MC3T3 cell differentiation, we carried out ALP activity detection. As shown in Fig. 3a, except for FC002 and SAT05f, all the other ODNs could markedly improve the ALP activity of MC3T3 cells at 24 and $48 \mathrm{~h}$, compared with the control group (Fig. 3a). Similar with the MTT assay, we found these effects were attenuated along with treatment time, except for BW001 and FC001, which demonstrated a significantly consistent increase over time $(P<0.05)$. The ALP staining test at 7 days showed that BW001, FC001, BW006, YW002, YW001, FC004 and MT01 kept significant promotion effect of MC3T3 cell differentiation (Fig. 3b). Therefore, we selected ODNs of BW001, FC001, BW006, YW002, YW001 and FC004 for the following experimental study.

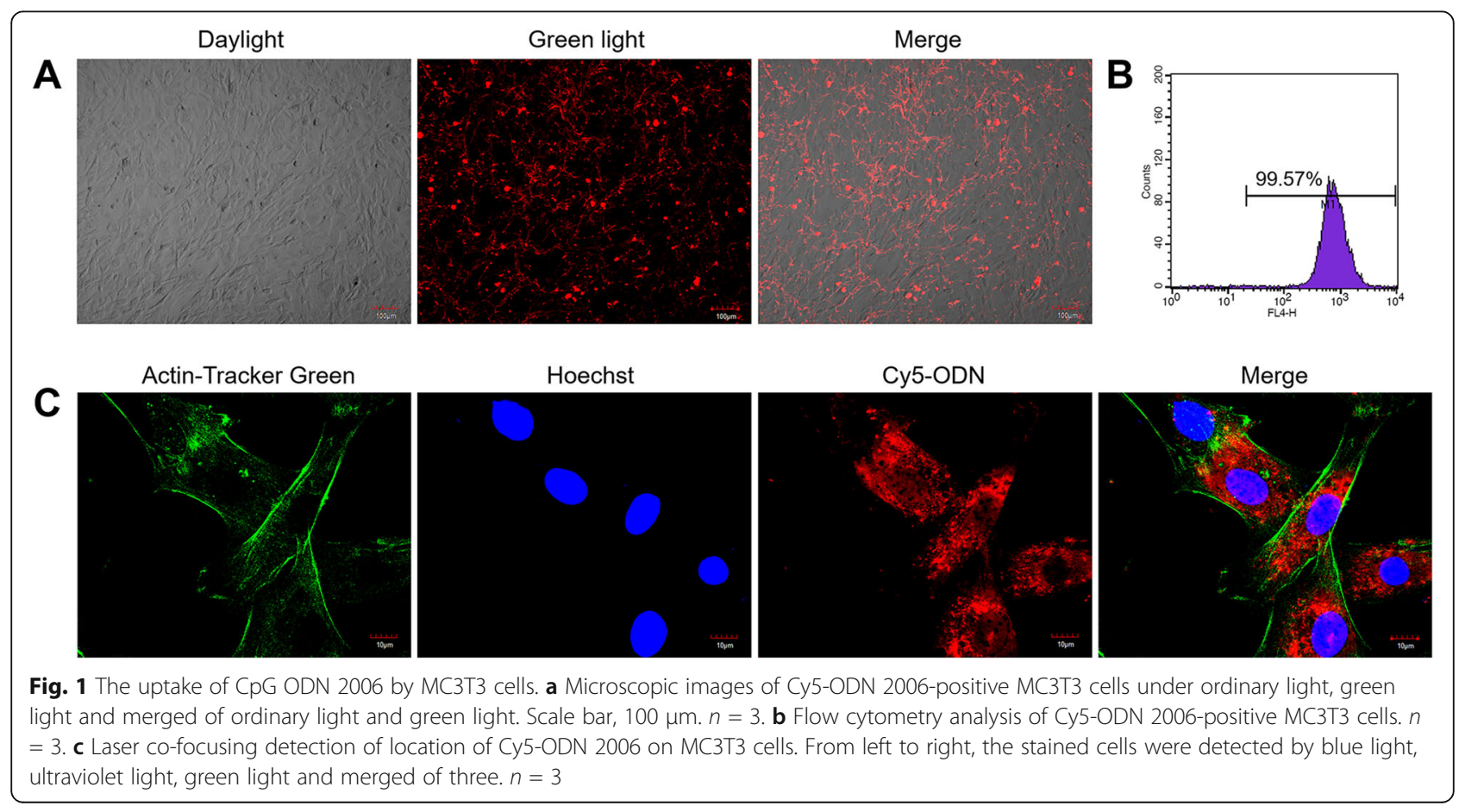




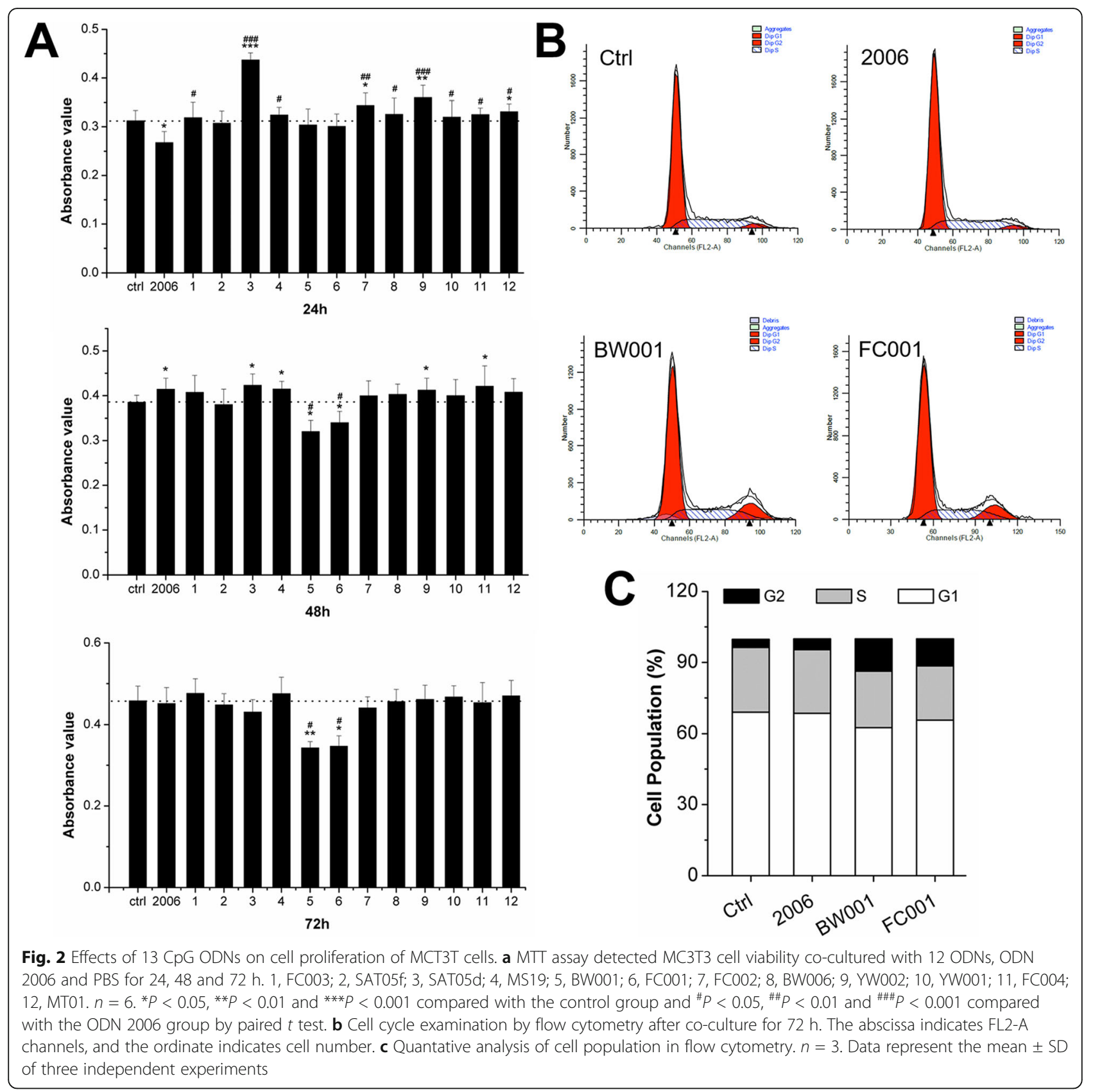

CpG ODNs could increase the relative expression of osteogenic differentiation genes SP7 and OCN

The relative expression levels of osteogenic differentiated genes, SP7 and OCN, were detected through qRT-PCR assay at 1 day, 3 days and 5 days. We found that the relative expression of SP7 and OCN were significantly upregulated by these CpG ODNs and the relative expression level reached to the peak on day $3(P<0.05)$. In addition, the upregulation of SP7 was more significant than that of OCN. Moreover, the effect of BW001 and FC001 on the increasing gene level was significantly higher than that in the ODN 2006 group, while the effect of BW006, YW002, YW001 and FC004 was weaker (Fig. 4a). Western blot results exhibited that the six selected CpG ODNs significantly promoted the protein expression of SP7 and OCN, and the promotion of SP7 was stronger than OCN, which were consistent with the results of qRT-PCR (Fig. 4b). Therefore, BW001, FC001, BW006, YW002, YW001 and FC004 improved the osteogenic differentiation of MC3T3 cells at the gene and protein levels. 


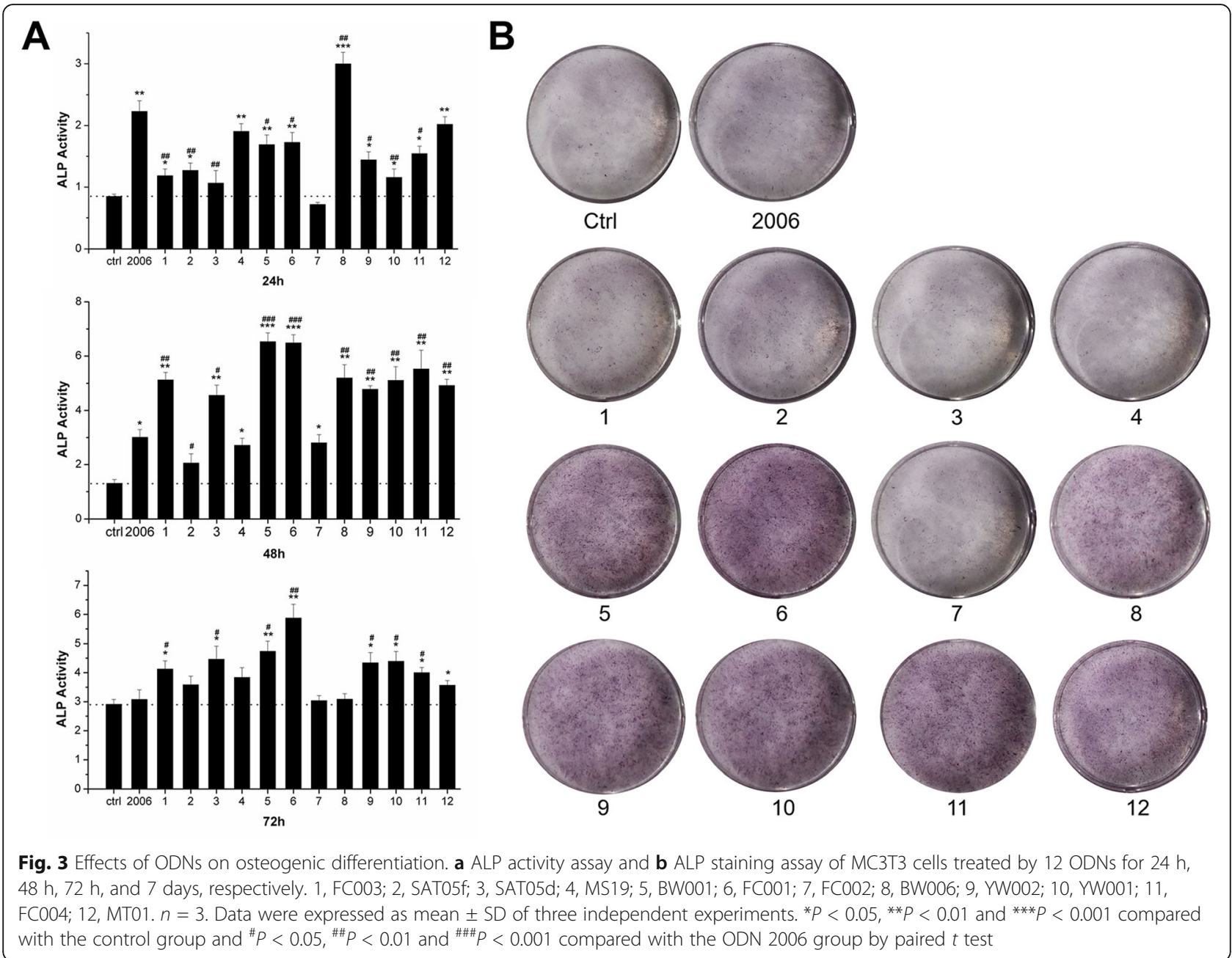

BW001 and FC001 CpG ODN decrease the protein expression of cyclin D1 and promote the expression of Runx2

In previous results, BW001 and FC001 exhibited an inverse association between the proliferation and differentiation of MC3T3 cells. To explore the potential mechanism of different effect of BW001 and FC001 on MC3T3 cell proliferation and differentiation, we examined the protein expression of cyclin D1 and Runx2 under treatment of BW001 and FC001. As shown in Fig. 5, BW001 and FC001 induced significant expression of $\mathrm{P} 27^{\mathrm{Kip} 1}$, which was an inhibitor of cyclin/CDKs (like cyclin D1, cyclin A and cyclin E). With the elevation of $\mathrm{P} 27^{\mathrm{Kip} 1}$, protein expression of cyclin D1 was decreased while the expression of Runx2 was enhanced by BW001 and FC001 (Fig. 5).

\section{Discussion}

In this study, 12 kinds of CpG ODNs including FC003, SAT05f, SAT05d, MS19, BW001, FC001, FC002, BW006, YW002, YW001, FC004 and MT01 were synthesized, and their roles on proliferation and differentiation of osteoclasts were investigated. Results showed that 90\% CpG ODN could be uptaken by MC3T3 cells in $1 \mathrm{~h}$ and located in the cell cytoplasm. MTT assay demonstrated CpG ODNs could promote MC3T3 cell proliferation and differentiation in the early stage, and gradually attenuated along with the increase of treating time, except for BW001 and FC001. qRT-PCR assay demonstrated that all the $12 \mathrm{CpG}$ ODNs could promote the relative expression level of osteogenic differentiated genes, SP7 and OCN. In addition, western blot analysis suggested the CpG ODNs of BW001 and FC001 could increase the protein expression of $\mathrm{P} 27^{\mathrm{Kip} 1}$ and Runx2 and decrease the protein expression of cyclin D1.

CpG ODN is widely used in the research and treatment of immunology. However, crucial problems, such as degradability by nuclease and low uptake by cells, would limit its wide clinical application. To overcome this disadvantage, researchers employ chemical modifications of ODN. Among them, phosphorothioate of ODN achieved more stability against enzymatic degradation [16, 17]. CpG ODN is uptaken into cells by receptor-mediated 


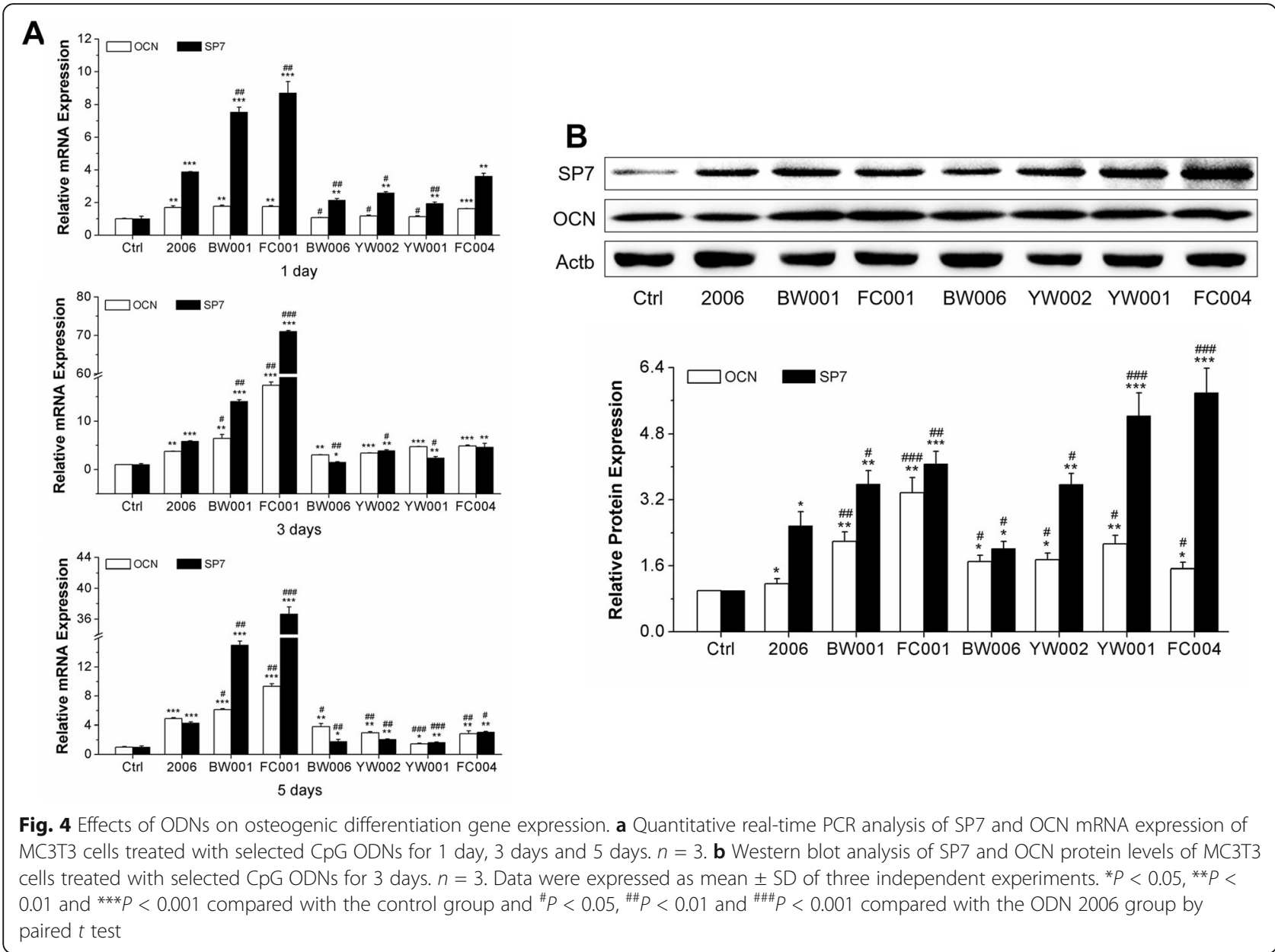

endocytosis, and this process requires amount of energy and is closely related to temperature and time [18]. CpG ODN enters the endosomes via PI3K, then specially interacted by TLR9 in the endosomes. The MT01 ODN was confirmed to enter MG63 cells by endocysis in Hou's study [19], and the uptake of MT01 ODN became to increase to peak on $12 \mathrm{~h}$. However, in this study, CpG ODN reached more than 90\% tranfection efficiency in $1 \mathrm{~h}$. In addition, CpG ODN can also enter into cells by delivery vehicle. In the study of Zhang [20] and Zheng [21], they respectively applied graphene oxide-chitosan nanocomposites and $\mathrm{N}$-isopropylacrylamide-modified polyethylenimine (PEN) to achieve delivery of CpG ODN into RAW264.7 cells and MG63 cells, and both abtained higher transfection. Noteworthily, in our study, the Cy5CpG ODN mainly located in the cytoplasm, which was similar to the results of Hou and Zhang. This was in accordance with the location of TLR9 in the endolysosome $[5,20,22]$. Therefore, the phosphorothioate CpG ODN not only rapidly and efficiently entered the cells, but also located in the cytoplasm.

Previously, Shen [12] and Feng [13] reported that MT01, SAT05d, BW001, FC002, YW001 and FC004 could be able to promote the proliferation while BW001, BW006, MT01, FC001, FC002, FC004, YW001, and YW002 could stimulate the differentiation of BMSCs to osteoblasts. Our results showed that FC003, SAT05f, SAT05d, MS19, FC002, BW006, YW002, YW001, FC004 and MT01 could promote MC3T3 cell proliferation and differentiation. These results were partly in consistent with the study of Shen and Feng. Besides, we found that the effects of these ODNs on cell proliferation and differentiation were gradually attenuated along with the increase of treating time, indicating the effect of CpG ODNs on proliferation and differentiation of MC3T3 cells occurred in the early stage. This result was in line with Feng et al. who showed that ODN FC002, MT01 and YW001 significantly induced ALP activity at $24 \mathrm{~h}$ while there was no statistically significant difference between them and the control group.

Besides, in our study, we found that the effect of ODNs BW001 and FC001 were different with other ODNs. They showed inhibition effects on cell proliferation and differentiation, and these effects were enhanced but not attenuated along with treating time. This result is also different with the results of Shen and Feng. Cell cycle analysis suggested that BW001 and FC001 could block MC3T3 cells in G2 phase. 

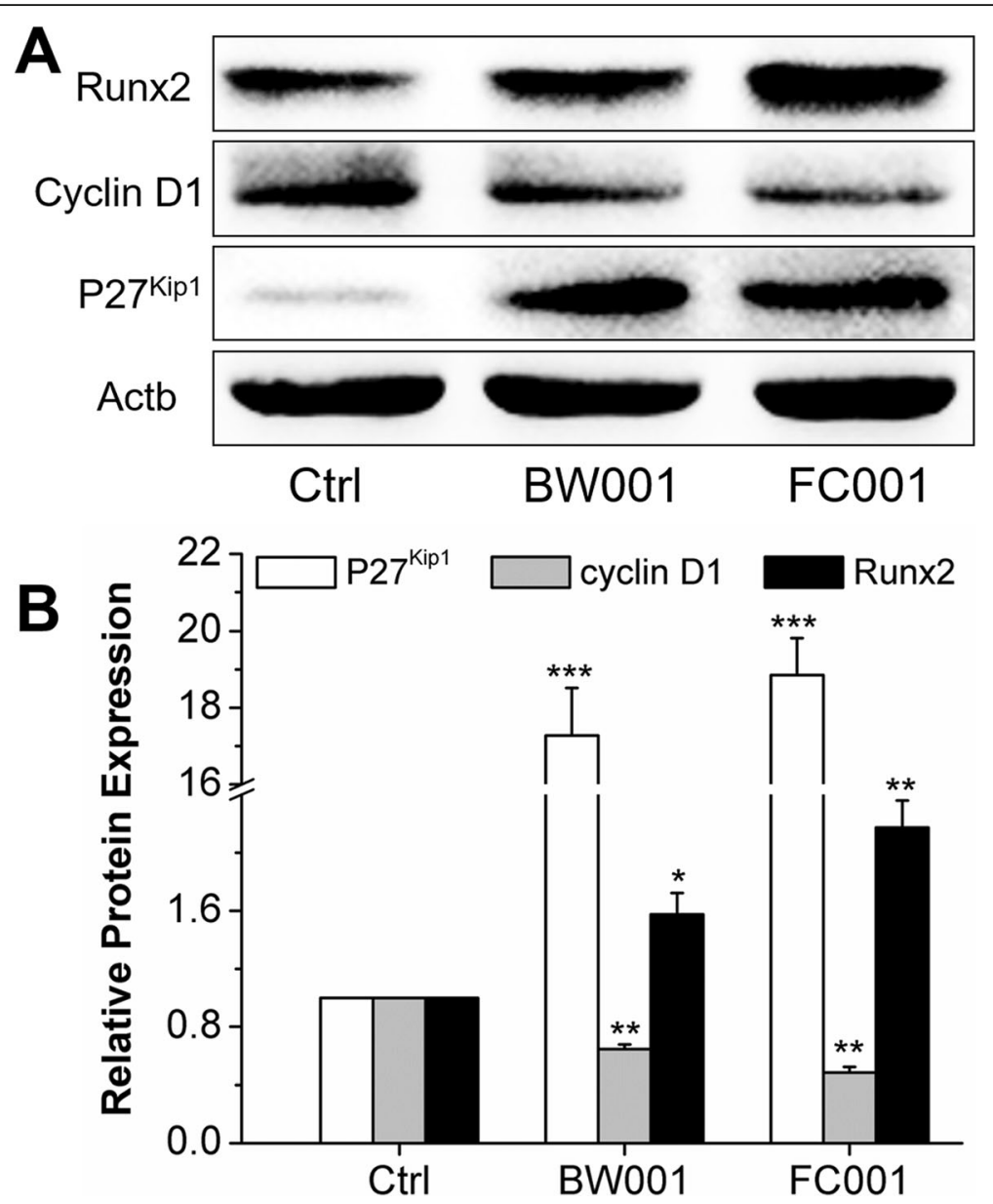

Fig. 5 Effects of BW001 and FC001 on protein expression of the cyclin D1/Runx2 regulation network. a Western blot analysis of P27 Kip1, cyclin D1 and Runx2 protein levels of MC3T3 cells treated with BW001 and FC001 for 3 days. b Quantative analysis of western blot analysis. Data were expressed as mean \pm SD of three independent experiments. ${ }^{*} P<0.05$ vs. the control group by paired $t$ test

Noteworthily, among these CpG ODNs, BW001 and FC001 led to an inverse effect on proliferation and differentiation of MC3T3 cells. This phenomenon could also be seen in many developmental processes, like myogenesis and neural development $[23,24]$. The researchers confirmed this effect might due to the consensus motif of cyclin-CDK phosphorylation locating at the serine residue of Runx2 phosphorylation site $[25,26]$. In our study, western blot analysis showed that the CpG ODNs of BW001 and FC001 could increase the protein expression of $\mathrm{P} 27^{\mathrm{Kip} 1}$ and Runx2 and decrease the protein expression of cyclin D1. P27 ${ }^{\text {Kip } 1}$ is an inhibitor of cyclin/CDKs (like cyclin D1, cyclin A and cyclin E) [27]. Runx2 was a specific transcription factor of osteogenic differentiation [28]. The active Runx2 initiated a series of osteogenic differentiated genes, such as SP7, OCN, OPN and ALP $[29,30]$. Galindo et al. confirmed that the mechanism of Runx2 inducing osteoblast differentiation involves the exit from cell cycle [31] and Runx2 can be degraded by cyclin D1-Cdk4 in an ubiquitination-proteasome-dependent manner [24]. Moreover, in our data, a dramatically enhanced
Runx2 and G2 phase were clearly observed. This was in consistent with Qiao [32], who demonstrated a maximal Runx2 activity existing in late $\mathrm{G} 2 / \mathrm{M}$ phase.

\section{Conclusion}

The phosphorothioate CpG ODN could efficiently enter the cells without vehicles and locate in the cytoplasm. The BW001 and FC001 inhibited the proliferation of MC3T3 cells by arresting cells in G2 phase. Moreover, we discovered six CpG ODNs (BW001, FC001, BW006, YW002, YW001 and FC004) that could significantly improve the differentiation of MC3T3 cells. Noteworthily, we found the underling potential mechanism of BW001 and FC001 about inverse regulation on proliferation and differentiation might attribute to cyclin proteins/Runx2 network. The selected CpG ODNs were expected to be a potential gene therapy for treating periodontitis inflammation and bone regeneration. 


\section{Acknowledgements}

None.

\section{Authors' contributions}

Conception and design of the research: Wenwen Yu. Acquisition of data: Yi Zheng. Analysis and interpretation of data: Hongyan Li, Hongbing Lin. Statistical analysis: Zhen Chen, Yue Tian, Huishan Chen. Drafting the manuscript: Wenwen Yu. Revision of the manuscript for important intellectual content: Peipei Zhang, Xiaowei Xu, Yuqin Shen. The author(s) read and approved the final manuscript.

\section{Funding}

This research was supported by grants from the Medical Support Program of the Jilin University (No. 20170311032 YY), Science and Technology Project of the Jilin Provincial Department of Finance (No.jcsz2020304-9), National Natural Science Foundation of China (No. 81970946 and No. 81600879) and the 13th Five-Year for Key Clinical Medical Subjects Construction of Tianjin (No. jmse268).

\section{Availability of data and materials}

The datasets used and/or analyzed during the current study are available from the corresponding author on reasonable request.

\section{Ethics approval and consent to participate}

Not applicable.

\section{Consent for publication}

Not applicable.

\section{Competing interests}

The authors declare that they have no competing interests. All authors read and approved the final manuscript.

\section{Author details}

${ }^{1}$ Department of Periodontics, School and hospital of Stomatology, Jilin University, 1500 Qinghua Road, Changchun, Jilin 130021, China. ${ }^{2}$ Department of Orthodontics, Tianjin Key Laboratory of Oral and Maxillofacial Function Reconstruction; Tianjin Stomatological Hospital; Hospital of Stomatology, Nankai University, 75 Dagu North Road, Tianjin 300041, China.

\section{Received: 9 May 2020 Accepted: 30 July 2020}

\section{Published online: 14 August 2020}

\section{References}

1. Azuma M. Fundamental mechanisms of host immune responses to infection. J Periodontal Res. 2006;41(5):361-73. https://doi.org/10.1111/j. 1600-0765.2006.00896.X.

2. Huang Q, Yang J, Lin Y, Walker C, Cheng J, Liu ZG, et al. Differential regulation of interleukin 1 receptor and Toll-like receptor signaling by MEKK3. Nat Immunol. 2004:5(1):98-103. https://doi.org/10.1038/ni1014.

3. Zou W, Schwartz H, Endres S, Hartmann G, Bar-Shavit Z. CpG oligonucleotides: novel regulators of osteoclast differentiation. FASEB journal: official publication of the Federation of American Societies for Experimental Biology. 2002;16(3):274-82. https://doi.org/10.1096/fj.010586com.

4. Farrokhi S, Abbasirad N, Movahed A, Khazaei HA, Pishjoo M, Rezaei N. TLR9based immunotherapy for the treatment of allergic diseases. Immunotherapy. 2017;9(4):339-46. https://doi.org/10.2217/imt-2016-0104.

5. Krieg AM. CpG motifs: the active ingredient in bacterial extracts? Nat Med. 2003;9(7):831-5. https://doi.org/10.1038/nm0703-831.

6. Hemmi H, Takeuchi O, Kawai T, Kaisho T, Sato S, Sanjo H, et al. A Toll-like receptor recognizes bacterial DNA. Nature. 2000;408(6813):740-5. https://doi. org/10.1038/35047123.

7. Jakob T, Walker PS, Krieg AM, Udey MC, Vogel JC. Activation of cutaneous dendritic cells by CpG-containing oligodeoxynucleotides: a role for dendritic cells in the augmentation of Th1 responses by immunostimulatory DNA. J Immunol. 1998;161(6):3042-9.

8. Kim IY, Yan X, Tohme S, Ahmed A, Cordon-Cardo C, Shantha Kumara HM et al. CPG ODN, Toll like receptor (TLR)-9 agonist, inhibits metastatic colon adenocarcinoma in a murine hepatic tumor model. J Surg Res. 2012;174(2): 284-90. https://doi.org/10.1016/j.jss.2010.12.021.
9. Krieg AM. Therapeutic potential of Toll-like receptor 9 activation. Nat Rev Drug Discov. 2006;5(6):471-84. https://doi.org/10.1038/nrd2059.

10. Amcheslavsky A, Hemmi H, Akira S, Bar-Shavit Z. Differential contribution of osteoclast- and osteoblast-lineage cells to CpG-oligodeoxynucleotide (CpGODN) modulation of osteoclastogenesis. J Bone Miner Res Off J Am Soc Bone Miner Res. 2005;20(9):1692-9. https://doi.org/10.1359/JBMR.050515.

11. Amcheslavsky A, Zou W, Bar-Shavit Z. Toll-like receptor 9 regulates tumor necrosis factor-alpha expression by different mechanisms. Implications for osteoclastogenesis. J Biol Chem. 2004;279(52):54039-45. https://doi.org/10. 1074/jbc.M409138200.

12. Shen $Y$, Feng $Z$, Lin C, Hou X, Wang $X$, Wang J, et al. An oligodeoxynucleotide that induces differentiation of bone marrow mesenchymal stem cells to osteoblasts in vitro and reduces alveolar bone loss in rats with periodontitis. Int J Mol Sci. 2012;13(3):2877-92. https://doi. org/10.3390/ijms13032877.

13. Feng $Z$, Shen $Y$, Wang $L$, Cheng $L$, Wang J, Li Q, et al. An oligodeoxynucleotide with promising modulation activity for the proliferation and activation of osteoblast. Int J Mol Sci. 2011;12(4):2543-55. https://doi.org/10.3390/ijms12042543.

14. Scheiermann J, Klinman DM. Clinical evaluation of CpG oligonucleotides as adjuvants for vaccines targeting infectious diseases and cancer. Vaccine. 2014;32(48):6377-89. https://doi.org/10.1016/j.vaccine.2014.06.065.

15. Yu X, Wang Y, Lin J, Hu Y, Kawai T, Taubman MA, et al. Lipopolysaccharidesinduced suppression of innate-like B cell apoptosis is enhanced by CpG oligodeoxynucleotide and requires Toll-like receptors 2 and 4. PLoS One. 2016;11(11):e0165862. https://doi.org/10.1371/journal.pone.0165862.

16. Kurreck J. Antisense technologies. Improvement through novel chemical modifications. Eur J Biochem. 2003;270(8):1628-44. https://doi.org/10.1046/j. 1432-1033.2003.03555.X.

17. Wang Y, Feng Q, Ji C, Liu X, Li L, Luo J. RUNX3 plays an important role in mediating the BMP9-induced osteogenic differentiation of mesenchymal stem cells. Int J Mol Med. 2017;40(6):1991-9. https://doi.org/10.3892/ijmm. 2017.3155.

18. Klinman DM. Immunotherapeutic uses of $\mathrm{CpG}$ oligodeoxynucleotides. Nat Rev Immunol. 2004;4(4):249-58. https://doi.org/10.1038/nri1329.

19. Hou $X$, Shen $Y$, Zhang $C$, Zhang L, Oin Y, Yu Y et al. A specific oligodeoxynucleotide promotes the differentiation of osteoblasts via ERK and p38 MAPK pathways. Int J Mol Sci. 2012;13(7):7902-14. https://doi.org/ 10.3390/ijms13077902.

20. Zhang H, Yan T, Xu S, Feng S, Huang D, Fujita M, et al. Graphene oxidechitosan nanocomposites for intracellular delivery of immunostimulatory CpG oligodeoxynucleotides. Mater Sci Eng C Mater Biol Appl. 2017;73:14451. https://doi.org/10.1016/j.msec.2016.12.072.

21. Zheng $Y$, Lin C, Hou X, Ma N, Yu W, Xu X, et al. Enhancing the osteogenic capacity of MG63 cells through $\mathrm{N}$-isopropylacrylamide-modified polyethylenimine-mediated oligodeoxynucleotide MT01 delivery. RSC Adv 2017;7(43):27121-7. https://doi.org/10.1039/c6ra27182k

22. Bauer S, Kirschning CJ, Hacker H, Redecke V, Hausmann S, Akira S, et al. Human TLR9 confers responsiveness to bacterial DNA via species-specific CpG motif recognition. Proc Natl Acad Sci U S A. 2001;98(16):9237-42. https://doi.org/10.1073/pnas.161293498.

23. Thomas DM, Carty SA, Piscopo DM, Lee JS, Wang WF, Forrester WC, et al. The retinoblastoma protein acts as a transcriptional coactivator required for osteogenic differentiation. Mol Cell. 2001;8(2):303-16. https://doi.org/10. 1016/s1097-2765(01)00327-6.

24. Shen R, Wang X, Drissi H, Liu F, O'Keefe RJ, Chen D. Cyclin D1-cdk4 induce runx2 ubiquitination and degradation. J Biol Chem. 2006;281(24):16347-53. https://doi.org/10.1074/jbc.M603439200.

25. Zhang $M$, Xie R, Hou W, Wang B, Shen R, Wang X, et al. PTHrP prevents chondrocyte premature hypertrophy by inducing cyclin-D1-dependent Runx2 and Runx3 phosphorylation, ubiquitylation and proteasomal degradation. $J$ Cell Sci. 2009;122(Pt 9):1382-9. https://doi.org/10.1242/jcs.040709.

26. Tane S, Ikenishi A, Okayama H, Iwamoto N, Nakayama Kl, Takeuchi T. CDK inhibitors, p21(Cip1) and p27(Kip1), participate in cell cycle exit of mammalian cardiomyocytes. Biochem Biophys Res Commun. 2014;443(3): 1105-9. https://doi.org/10.1016/j.bbrc.2013.12.109.

27. Pestell RG. New roles of cyclin D1. Am J Pathol. 2013;183(1):3-9. https://doi. org/10.1016/j.ajpath.2013.03.001.

28. Komori T. Runx2, a multifunctional transcription factor in skeletal development. J Cell Biochem. 2002:87(1):1-8. https://doi.org/10.1002/jcb. 10276. 
29. Komori T. Requisite roles of Run $\times 2$ and Cbfb in skeletal development. J Bone Miner Metab. 2003;21(4):193-7. https://doi.org/10.1007/s00774-002 0408-0.

30. Komori T. Regulation of bone development and maintenance by Runx2 Front Biosci. 2008;13:898-903. https://doi.org/10.2741/2730.

31. Galindo M, Pratap J, Young DW, Hovhannisyan H, Im HJ, Choi JY, et al. The bone-specific expression of Runx2 oscillates during the cell cycle to support a G1-related antiproliferative function in osteoblasts. J Biol Chem. 2005; 280(21):20274-85. https://doi.org/10.1074/jbc.M413665200.

32. Qiao M, Shapiro P, Fosbrink M, Rus H, Kumar R, Passaniti A. Cell cycledependent phosphorylation of the RUNX2 transcription factor by cdc2 regulates endothelial cell proliferation. J Biol Chem. 2006;281(11):7118-28. https://doi.org/10.1074/jbc.M508162200.

\section{Publisher's Note}

Springer Nature remains neutral with regard to jurisdictional claims in published maps and institutional affiliations.

Ready to submit your research? Choose BMC and benefit from:

- fast, convenient online submission

- thorough peer review by experienced researchers in your field

- rapid publication on acceptance

- support for research data, including large and complex data types

- gold Open Access which fosters wider collaboration and increased citations

- maximum visibility for your research: over $100 \mathrm{M}$ website views per year

At BMC, research is always in progress.

Learn more biomedcentral.com/submissions 